\title{
Design and Development of Vancomycin Liposomes
}

\author{
Srinivas Lankalapalli*, Venkata Satya Vinai Kumar Tenneti, Sunil Kumar Nimmali \\ GITAM Institute of Pharmacy, GITAM University, Rushikonda, Visakhapatnam, Andhra Pradesh, India.
}

\begin{abstract}
Vancomycin hydrochloride is water soluble and poorly absorbable glycopeptide antibiotic act by inhibition of the synthesis of peptidoglycan a major component of bacteria cell wall. It is highly effective against the Staphylococcus aureus and other Staphylococcus species microorganisms. Structurally vancomycin hydrochloride has six peptide bonds with a molecular weight of approximately $1500 \mathrm{Da}$. Liposomes, the colloidal vesicular structures due to their biphasic environment can act as carriers for both lipophilic \& hydrophilic drugs. The encapsulation of antimicrobials in liposomes potentially offers enhanced pharmacokinetics and pharmacodynamics and decreased toxicity. This delivery system has the advantages of targeted, long circulation, low toxicity, sustained-release, no immunogenicity and protecting the encapsulated drugs from the destructive action of the external media. The present research work is planned to develop liposomal formulation of Vancomycin hydrochloride and to study the possibility of permeability enhancement. Liposomes are prepared by using various permeation enhancers like propylene glycol, poly ethylene glycol 400, poly ethylene glycol 600, Tween 80 and Span 60. The prepared liposomes are characterized by optical microscopy, scanning electron microscopy, particle size determination, encapsulation efficiency, FTIR spectroscopy studies and in vitro diffusion studies using dialysis membrane. Among six different liposomes F2 formulation (containing propylene glycol) has showed promising results with respect to drug entrapment and percentage drug release.
\end{abstract}

Key words: Liposomes, Phospholipids Permeability Enhancement, Poly ethylene glycol, Propylene glycol, Surfactants, Vancomycin Hydrochloride.

\section{INTRODUCTION}

Vancomycin hydrochloride (vancomycin) is a glycopeptide antibiotic act by inhibition of the synthesis of peptidoglycan a major component of bacteria cell wall. It shows a high antibacterial activity against Staphylococcus aureus and other Staphylococcus species. ${ }^{1-3}$ Vancomycin hydrochloride is considered for the treatment of septicimia, lower respiratory tract, skin, and bone infections caused by gram positive bacteria. Vancomycin hydrochloride is reported to be effective at a minimum inhibitory concentration of $2 \mu \mathrm{g} / \mathrm{mL}$ against methicillin-resistant Staphylococcus aureus (MRSA). ${ }^{4-9}$ Structurally Vancomycin hydrochloride has six peptide bonds with a molecular weight of approximately 1500 Da. ${ }^{10} \mathrm{It}$ is water soluble and poorly absorbed from the gastrointestinal (GI) tract. ${ }^{10}$ There are very few investigations reported for improving the GI absorption of Vancomycin hydrochloride by using strategies such as multiple emulsions ${ }^{11}$ liposomes ${ }^{12}$ and using sodium glycocholate as absorption promoter. ${ }^{13}$

Liposomes, the colloidal vesicular structures due to their biphasic environment can act as carriers for both lipophilic \& hydrophilic drugs. High hydrophilic drug $(\log \mathrm{p}<-0.3)$ are located exclusively in the aqueous domains, whereas highly lipophilic drugs $(\log P>5)$ are entrapped within the lipid bilayers of the liposomes. ${ }^{14}$ The encapsulation of antimicrobials in liposomes potentially offers enhanced pharmacokinetics and pharmacodynamics and decreased toxicity. ${ }^{15}$ This delivery system has the advantages of targeted, long circulation, low toxicity, sustained-release, no immunogenicity and protecting the encapsulated drugs from the destructive action of the external media. ${ }^{16-}$ ${ }^{21}$ Hence in the present research work it is planned to develop liposomal formulation
Submission Date : 07.06.2014 Revision Date : :18.08.2014 Accepted Date : :07.01.2015

DOI: 10.5530/ijper.49.3.6 Correspondence Address Dr. L. Srinivas Professor,

GITAM Institute of Pharmacy, GITAM University,

Rushikonda, Visakhapatnam Andhra Pradesh, India.

E-mail:Isrinivas2001@gitam. edu

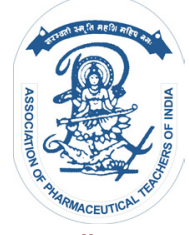

www.ijper.org 
of Vancomycin hydrochloride and to study the effect of different permeability enhancers. Liposomes are prepared by solvent injection method using various excipients like soya lecithin, cholesterol and co-solvents like ethanol, chloroform, propylene glycol (PG), poly ethylene glycol 400 (PEG-400), poly ethylene glycol 600 (PEG-600) and surfactants like Tween 80 and Span 60 etc. The prepared liposomes are characterized by optical microscopy, scanning electron microscopy, particle size determination, encapsulation efficiency, FTIR spectroscopy studies and in vitro diffusion studies using dialysis membrane.

\section{MATERIALS AND METHODS}

\section{Materials}

Vancomycin hydrochloride was a gift sample from $\mathrm{M} / \mathrm{s}$. TherDose Pharma Private Limited, Hyderabad. Soya lecithin and dialysis membrane-50 (Molecular Weight. cut off 12000 to 14000 ) was obtained from M/s. HiMedia Laboratories, Mumbai. Cholesterol was obtained from M/s. Finar Chemicals Limited, Ahmedabad. Chloroform, ethanol, propylene glycol, polyethylene glyco 1400 and polyethylene glyco 1600 were obtained from M/s. Sisco Research Laboratories Pvt. Ltd. Andheri (E), Mumbai. Tween 80 and Span 60 were obtained from M/s. Loba Chemie Pvt.Ltd. Potassium dihydrogen phosphate was obtained from M/s. Merck Specialities Pvt. Ltd., Mumbai. Sodium hydroxide was obtained from M/s. Qualigens Fine Chemicals, Mumbai. All other materials used in this study were of analytical grade.

\section{Preparation of vancomycin liposomes}

Liposomes were prepared by ethanol injection method using different formulations as shown in Table 1. In this method, initially weighed quantities of lecithin $(50 \mathrm{mg})$ and cholesterol $(20 \mathrm{mg}$ ) were dissolved in $10 \mathrm{ml}$ volume of chloroform: ethanol (1:1) solvent mixture in a $50 \mathrm{ml}$ beaker. To this lipid phase accurately weighed quantity of vancomycin $(10 \mathrm{mg})$ was added and dissolved. In case of formulations F2 to F6, the co solvents and surfactants were added to lipid phase. In another beaker $10 \mathrm{ml}$ of phosphate buffer $\mathrm{pH} 7.4$ was taken and kept for stirring at $200 \mathrm{rpm}$ on thermostatically controlled magnetic stirrer (Remi Magnetic Stirrer, Model: LBMS5886) at a temperature of $45^{\circ} \mathrm{C}$. To this aqueous phase, drug containing lipid phase was added by injection at one jet. The mixture was continued stirring for 1 hour to allow the solvent evaporation and to obtain uniform vesicular dispersion. Finally the liposome dispersion was stored in airtight container at $2-8^{\circ} \mathrm{C}$.

\section{Characterization of Liposomes}

\section{Optical microscopy}

The prepared vancomycin liposomes were viewed under phase contrast optical microscope (Olympus DSX 100) for observing the vesicle formation and discreteness of dispersed vesicles. A slide was prepared by placing a drop of liposome dispersion on a glass slide and cover slip was placed over it and this slide was viewed under optical microscope at $100 \mathrm{X}$ magnification. Photographs were taken to prepared slides using digital camera.

\section{Scanning Electron Microscopy (SEM)}

Scanning electron microscopy was used to characterize the surface morphology of the prepared vesicles. One drop of liposomal dispersion was mounted on a clearglass stub, air-dried, coated with Polaron E 5100 sputter coater (Polaron, Watford, United Kingdom), and visualized under a scanning electron microscope (Leo-435 VP; Leo, Cambridge, United Kingdom

\begin{tabular}{|c|c|c|c|c|c|c|}
\hline \multicolumn{7}{|c|}{ Table 1: Preparation of vancomycin liposomes formulation } \\
\hline INGREDIENTS & F1 & F2 & F3 & F4 & F5 & F6 \\
\hline Lecithin & $50 \mathrm{mg}$ & $50 \mathrm{mg}$ & $50 \mathrm{mg}$ & $50 \mathrm{mg}$ & $50 \mathrm{mg}$ & $50 \mathrm{mg}$ \\
\hline Cholesterol & $20 \mathrm{mg}$ & $20 \mathrm{mg}$ & $20 \mathrm{mg}$ & $20 \mathrm{mg}$ & $20 \mathrm{mg}$ & $20 \mathrm{mg}$ \\
\hline Chloroform & $2 \mathrm{~mL}$ & $2 \mathrm{~mL}$ & $2 \mathrm{~mL}$ & $2 \mathrm{~mL}$ & $2 \mathrm{~mL}$ & $2 \mathrm{~mL}$ \\
\hline Ethanol & $2 \mathrm{~mL}$ & $2 \mathrm{~mL}$ & $2 \mathrm{~mL}$ & $2 \mathrm{~mL}$ & $2 \mathrm{~mL}$ & $2 \mathrm{~mL}$ \\
\hline $\begin{array}{c}\text { Vancomycin } \\
\text { hydrochloride }\end{array}$ & $10 \mathrm{mg}$ & $10 \mathrm{mg}$ & $10 \mathrm{mg}$ & $10 \mathrm{mg}$ & $10 \mathrm{mg}$ & $10 \mathrm{mg}$ \\
\hline $\begin{array}{c}\text { Phosphate } \\
\text { Buffer pH 7.4 }\end{array}$ & $10 \mathrm{~mL}$ & $10 \mathrm{~mL}$ & $10 \mathrm{~mL}$ & $10 \mathrm{~mL}$ & $10 \mathrm{~mL}$ & $10 \mathrm{~mL}$ \\
\hline PG & - & $10 \mathrm{mg}$ & - & - & - & - \\
\hline PEG-400 & - & - & $10 \mathrm{mg}$ & - & $10 \mathrm{mg}$ & - \\
\hline PEG-600 & - & - & - & - & $10 \mathrm{mg}$ & - \\
\hline Tween-80 & - & - & - & - & - \\
\hline Span-60 & - & - & - & & - \\
\hline
\end{tabular}




\section{Particle size determination}

The mean particle size was obtained by particle size analyzer (Malvern). The instrument measures the particle size based on the laser diffraction theory. The apparatus consists of a He-Ne laser beam of $632.8 \mathrm{~nm}$ focused with a minimum power of $5 \mathrm{~mW}$ using a Fourier lens to a point at the center of multielement detector and a sample holding unit ( $\mathrm{Su}$ cell). The sample was stirred using a stirrer before determining the vesicle size. The vesicle dispersion was diluted about 100 times in the deionized water. Diluted liposomal suspension was added to sample dispersion unit containing stirrer and stirred at high speed in order to reduce interparticles aggregation and laser beam was focused

\section{Drug entrapment efficiency}

The drug entrapment efficiency was calculated using the total drug content of liposome dispersion and unentrapped drug content of the dispersion. The total dug content of the dispersion is determined estimating total drug entrapped and unentrapped. $5 \mathrm{ml}$ of liposome dispersion was taken in a volumetric flask. The dispersion was subjected to sonication in bath sonicator (M/s. Remi) for 30 minutes. Then the mixture was filtered and estimated after suitable dilution at $280 \mathrm{~nm}$ wavelengths by using UV Visible Spectrophotometer (Shimadzu, UV1800). For the free unenetrapped drug, $5 \mathrm{ml}$ of the liposome dispersion subjected to centrifugation at $18000 \mathrm{rpm}$ using Remi centrifuge for $40 \mathrm{~min}$ at $5^{\circ} \mathrm{C}$. The supernatant clear solution was collected separately and the free drug present in the supernatant was estimated after suitable dilution at $280 \mathrm{~nm}$ wavelength by using UV Visible Spectrophotometer. The entrapment efficiency of all the formulation was calculated by using following formula.

Entrapment Efficiency $=\left\{1-\frac{\text { Unentrapped drug content }}{\text { Total drug content }}\right\} \times 100$

\section{Fourier Transform Infrared Spectroscopy (FTIR)}

To investigate any possible interaction between the drug and the excipients utilized under investigation FTIR spectrophotometry was used. The IR Spectra of pure drug (vancomycin) and the combination of drug with excipients were carried out by using FTIR spectrophotometer on Spectrum II Perkin Elmer with $\mathrm{KBr}$ background. Sample preparation includes grinding a small quantity of the sample with a purified salt usually potassium bromide finely to remove scattering effects from large crystals. The powder mixture was crushed in a mechanical die press to form a translucent pellet through which the beam of the spectrometer can pass. The pressed sample was carefully removed from the die and was placed in the FTIR sample holder. The IR spectrum was recorded from $4000 \mathrm{~cm}^{-1}$ to $400 \mathrm{~cm}^{-1}$.

\section{In vitro diffusion studies}

In vitro diffusion studies were carried by using Franz diffusion cell appratus. The capacity of the receptor compartment was $20 \mathrm{ml}$ and the area of the donor compartment exposed to receptor compartment was $1.41 \mathrm{~cm}^{2}$. Dialysis membrane-50 with molecular weight cut off 12000 to 14000 Da from Hi-Media Laboratories Pvt. Ltd having flat width of $24.26 \mathrm{~mm}$ and diameter of $14.3 \mathrm{~mm}$ with approximate capacity of $1.61 \mathrm{~mL} / \mathrm{cm}$ was used for the study. The membrane was soaked overnight in phosphate buffer $\mathrm{pH}$ 7.4. $10 \mathrm{ml}$ of prepared liposomal dispersion which contains $10 \mathrm{mg}$ of drug was taken and placed in the donor cell. Dialysis membrane was placed in between donor cell and receptor cell. $20 \mathrm{ml}$ of phosphate buffer ( $\mathrm{pH}$ 7.4) was taken in receptor cell to touch the bottom surface of dialysis membrane. The temperature of the receptor phase was maintained at 37 $\pm 0.5^{\circ} \mathrm{C}$ and the receptor compartment was stirred with magnetic stirrer to maintain homogeneous condition. The aliquots of $3 \mathrm{ml}$ were withdrawn at different time intervals. Fresh medium was used to replace with equal volume of the sample withdrawn. The samples were analyzed at $280 \mathrm{~nm}$ in a UV-Visible spectrophotometer and amount of drug released at different time intervals was calculated.

\section{Microbiological assay}

The microbiological assay of vancomycin was carried out by cup plate method. The nutrient agar medium was prepared, sterilized and inoculated with Staphylococcus aerius micro-organism at a temperature between (40 to 50$)^{\circ} \mathrm{C}$ and immediately pored the inoculated medium into petri plates to give a depth of (4 to 5) $\mathrm{mm}$ uniformly and kept aside for solidification. Small cavities of $10 \mathrm{~mm}$ diameter were made on solidified agar petri plates by using sterilized cylinder shaped borer. $500 \mu \mathrm{l}$ of the prepared standard solutions and sample solutions (i.e equivalent to $5 \mu \mathrm{g} / \mathrm{ml}$ and $10 \mu \mathrm{g} / \mathrm{ml}$ drug concentration) were added into each cavity. These petri plates are left for 1 to 4 hours at room temperature as a pre-incubation diffusion to minimize the effects of variation in time between different solutions. Prepared petri plates were incubated for 24 hours at $32-35^{\circ} \mathrm{C}$ and measured the diameter of circular inhibited zones.

\section{RESULTS AND DISCUSSION}

\section{Optical microscopy}

The microscopy photographs of prepared liposomes formulations F2 and F3 (as shown in Figure 1) which were viewed under phase contrast optical microscope indicated the lamellar structure of liposome. The shape of the vesicles is spherical and the vesicles are discrete in distribution. 


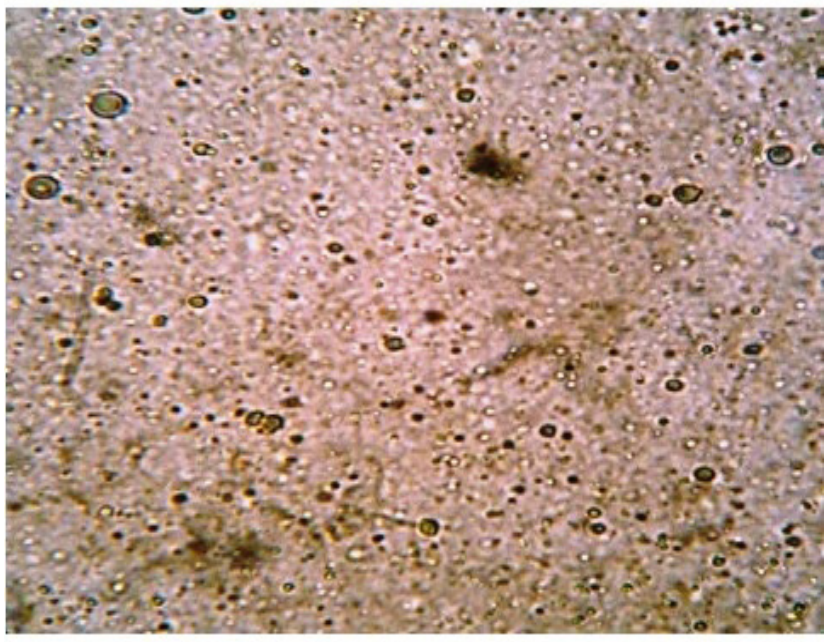

(a)

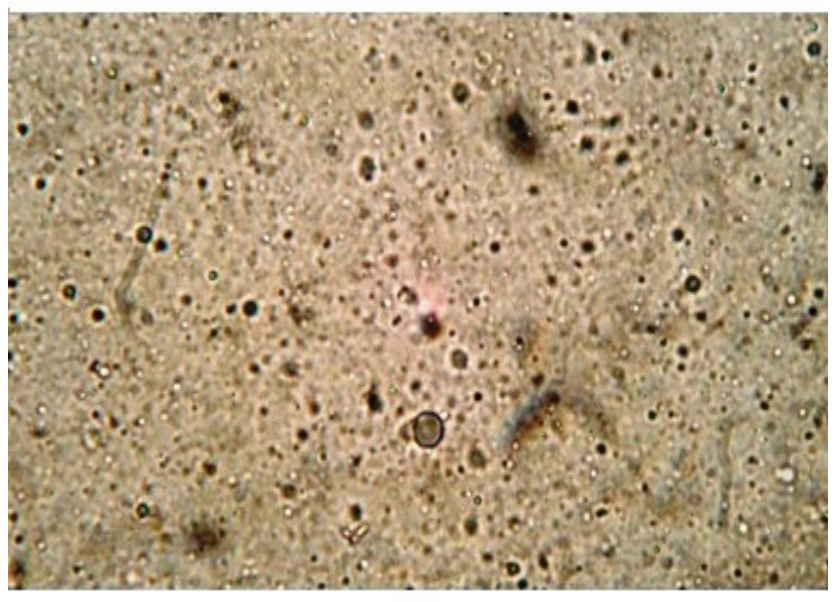

(b)

Figure 1: Optical Microscopic image of formulations (a) F2 (b) F3

\section{Scanning Electron Microscopy}

The Surface morphology of prepared liposome formulation of F-2 and vancomycin pure drug was studied by using Scanning Electron Microscopy and the images are shown in Figure 2. The images indicated the pure drug is irregular in shape. The liposome formulation F-2 showed spherical structures with smooth regular surface.

\section{Particle size determination}

The particle size distribution analysis was performed by using particle size analyzer (Malvern) and the results (Figure 3) showed that the average particle size of the liposome vesicle for formulation F2 was found to be $78.3 \mathrm{~nm}$ with poly disparity index of 0.184 . These results indicated that vesicle size is in nano particulate range and the size distribution is uniform.

\section{Fourier Transform Infrared Spectroscopy (FTIR)}

The FTIR spectra for vancomycin and vancomycin liposomes are shown in Figure 4. vancomycin FTIR

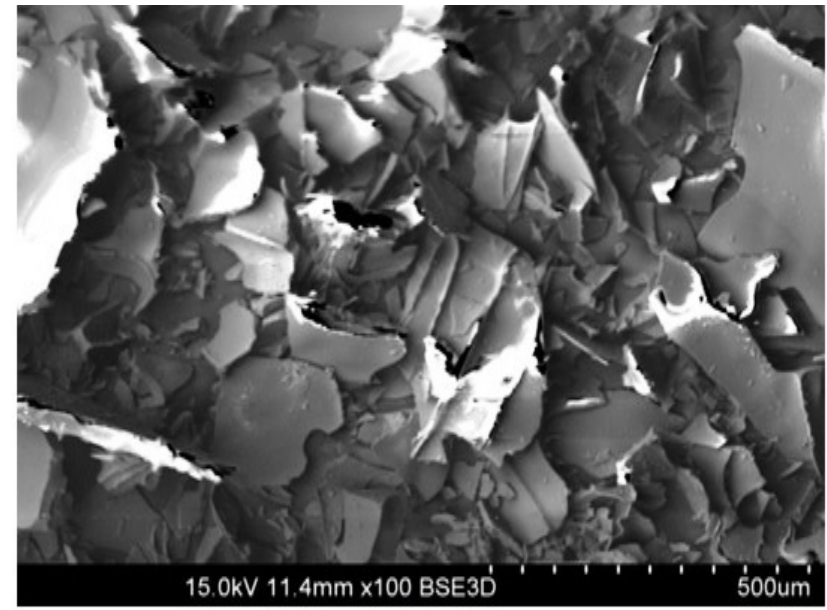

(a)

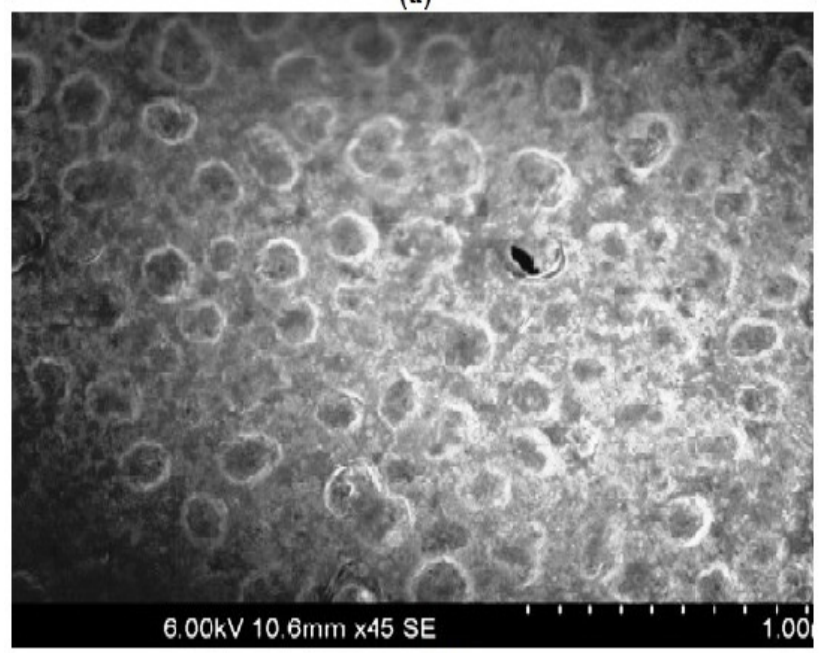

(b)

Figure 2: SEM Image of (a) vancomycin pure drug (b) F2 formulation

spectra showed that the characteristics peaks of functional group $\mathrm{COOH}$ at $3387.38 \mathrm{~cm}^{-1}, \mathrm{R}-\mathrm{CH}_{2}-\mathrm{CH}_{3}$ at $2935.51 \mathrm{~cm}^{-1}, \mathrm{R}-\mathrm{NH}-\mathrm{R}$ at $2842.19 \mathrm{~cm}^{-1}$, R-CO-NH at $1632.81 \mathrm{~cm}^{-1}, \mathrm{R}-\mathrm{O}-\mathrm{R}$ at $1093.52 \mathrm{~cm}^{-1}, \mathrm{R}-\mathrm{NH}_{2}$ at $687.81 \mathrm{~cm}^{-1}$. The FTIR spectra of prepared liposomes also showed all the major characteristic peaks at $3447.29,2924.48,2853.28,1634.82,1079.81,668.28$ $\mathrm{cm}^{-1}$ with minor shift. These results indicated that there is no interaction between drug and excepients used in the formulation.

\section{Drug Content and drug entrapment efficiency}

The percentage drug content and entrapment efficiency values are shown in Table 2 . The total drug content liposome formulations F1 to F6 were found to be in range $94.21 \%$ to $98.62 \%$. The entrapment efficiency (shown in Table 2) of formulations F1 to F6 was found to be in range $69.66 \%$ to $78.66 \%$. Among these formulations; F2 i.e. liposomes prepared by using propylene glycol showed highest entrapment efficiency of $78.66 \%$. 


\section{Size Distribution Report by Intensity v2.1}

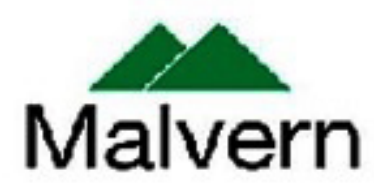

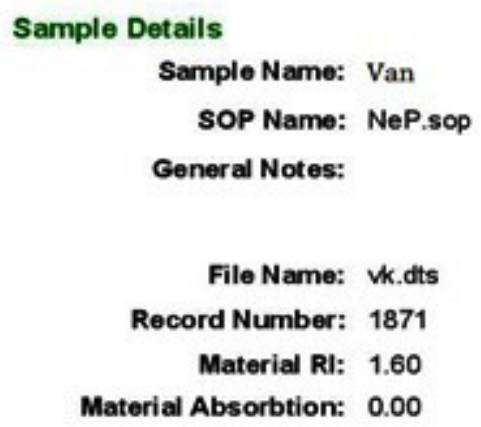

\section{System}

Temperature $\left({ }^{\circ} \mathrm{C}\right): 25.0$

Count Rate (kcps): 344.5

Cell Description: Disposable sizing cuvette
Dispersant Name: Water

Dispersant RI: 1.330

Viscosity (cP): 0.8872

Measurement Date and Time: Wedmesday,09:04:2014

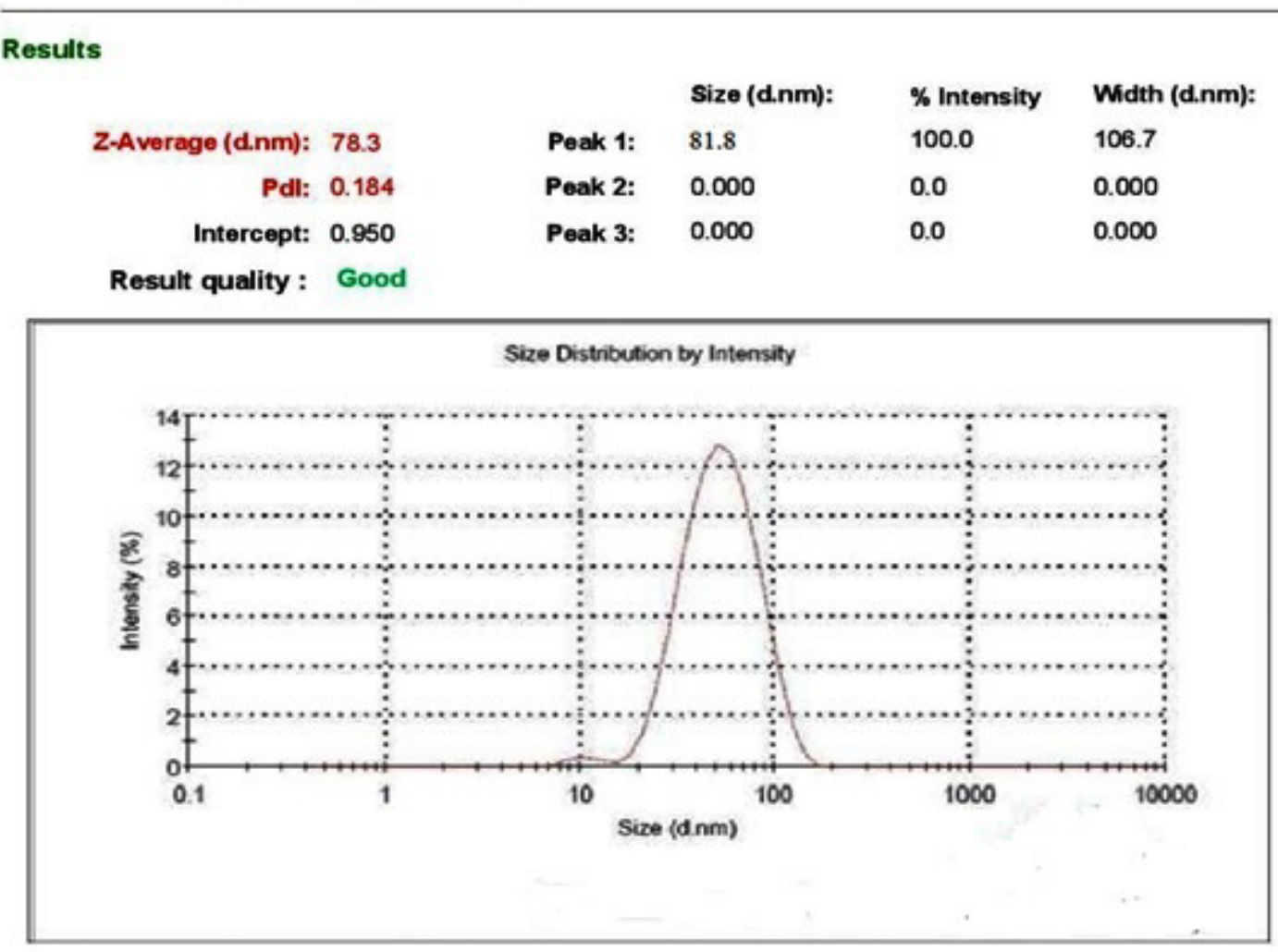

Figure 3: Particle size distribution of formulation F2 

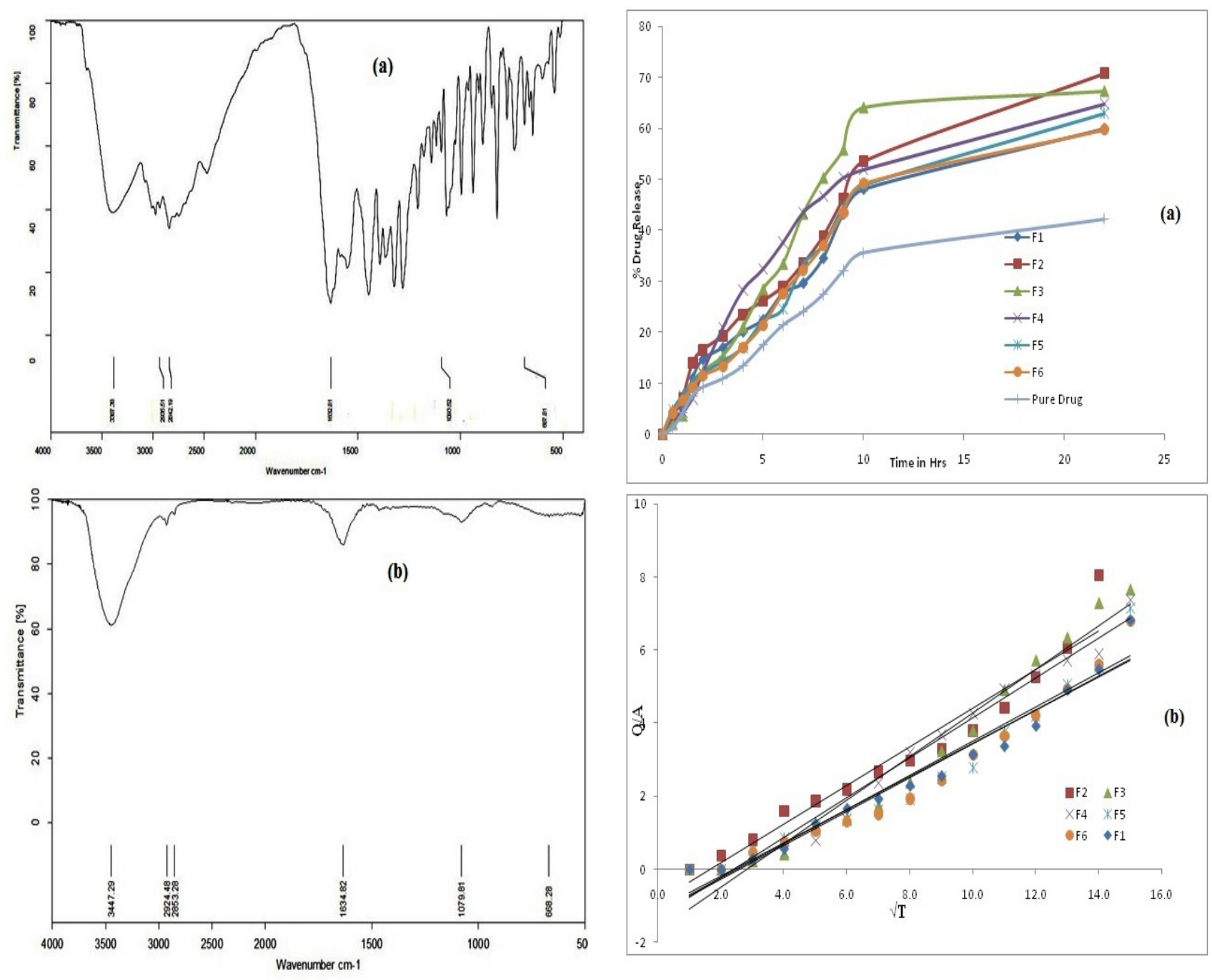

Figure 4: FTIR spectra of (a) vancomycin (b) formulation F2

Figure 5: In vitro diffusion studies and diffusion constant of Prepared Liposomes

\begin{tabular}{|c|c|c|c|}
\hline \multicolumn{2}{|c|}{$\begin{array}{c}\text { Table 2: Drug content, drug entrapment efficiency and Percentage drug of liposomal formulations } \\
\text { Formulation }\end{array}$} & Drug Entrapped & $\begin{array}{c}\text { Percentage drug release at } \\
\text { 22 hrs }\end{array}$ \\
\hline F1 & 72.10 & 96.12 & 60.00 \\
\hline F2 & 78.66 & 98.62 & 70.68 \\
\hline F3 & 77.33 & 97.12 & 67.33 \\
\hline F4 & 75.66 & 96.65 & 64.77 \\
\hline F5 & 74.10 & 96.32 & 62.88 \\
\hline F6 & 69.66 & 94.21 & 59.66 \\
\hline Pure drug & - & - & 42.30 \\
\hline
\end{tabular}

All the values are in $\%$

Whereas formulation F6 i.e. liposomes prepared by span 60 showed lowest percentage entrapment efficiency of $69.66 \%$.

\section{In vitro diffusion studies of prepared liposomes}

The results of in vitro drug diffusion studies are shown in Table 2. The drug diffusion through semi permeable membrane for the pure vancomycin was found to be 42.30 percent. Percentage drug release of formulations $\mathrm{F} 1$ to $\mathrm{F} 6$ were found to be in range (59.66 to 70.68$) \%$ at 22 hours. Among them the formulation F-2 showed highest percentage drug release of $70.68 \%$. Graphs were plotted (as shown in Figure 5) by calculating diffusion rate constant with $\mathrm{Q} / \mathrm{A}$ Vs square root of time, whereas $\mathrm{Q}$ is the percentage drug released and $\mathrm{A}$ is the area of Franz diffusion cell. These results sug- 
Table 3: Percentage Zone of Inhibition for prepared formulations

\begin{tabular}{|c|c|c|c|}
\hline Formulation & Concentration $(\mu \mathrm{g} / \mathrm{ml})$ & Log. Concentration & $\%$ Inhibition \\
\hline \multirow{2}{*}{ F1 } & 5 & 0.70 & 52.63 \\
\hline & 10 & 1.00 & 63.15 \\
\hline \multirow{2}{*}{ F2 } & 5 & 0.70 & 63.15 \\
\hline & 10 & 1.00 & 94.7 \\
\hline \multirow{2}{*}{ F3 } & 5 & 0.70 & 52.63 \\
\hline & 10 & 1.00 & 89.47 \\
\hline \multirow{2}{*}{ F4 } & 5 & 0.70 & 57.89 \\
\hline & 10 & 1.00 & 84.21 \\
\hline \multirow{2}{*}{ F5 } & 5 & 0.70 & 57.89 \\
\hline & 10 & 1.00 & 73.68 \\
\hline \multirow{2}{*}{ F6 } & 5 & 0.70 & 52.63 \\
\hline & 10 & 1.00 & 57.89 \\
\hline \multirow{4}{*}{ STD. } & 5 & 0.70 & 69.23 \\
\hline & 10 & 1.00 & 73.07 \\
\hline & 15 & 1.18 & 88.46 \\
\hline & 20 & 1.30 & 100 \\
\hline
\end{tabular}
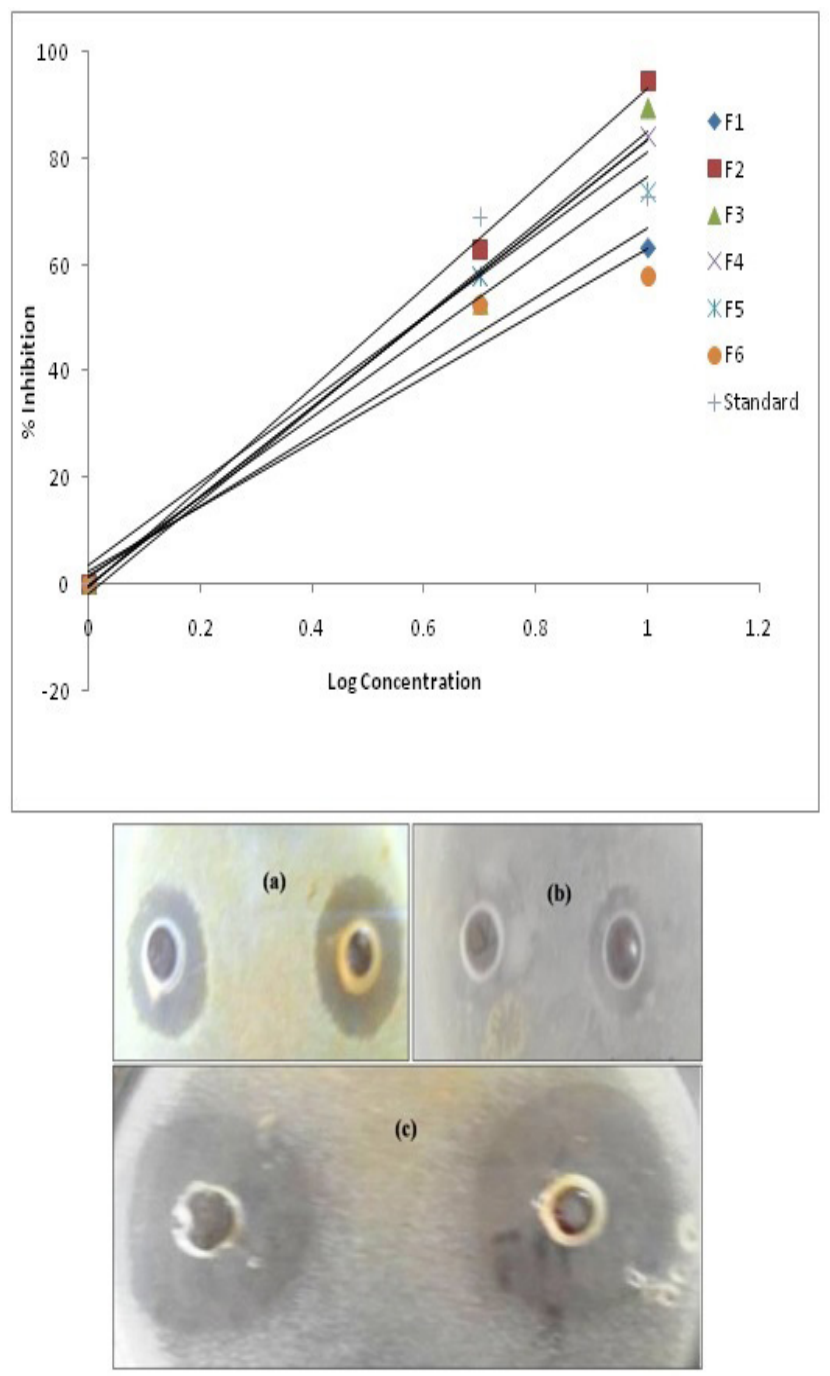

Figure 6: Microbiological assay studies and Zone of Inhibition for (a) Standard (b) Control (c) Formulation F2 gested that all types of co solvents such as PG, PEG400, PEG-600, Tween-80, and Span-60 have enhanced the rate of percentage drug release than the pure drug. Among them the liposomal formulation prepared with PG (F2) has shown highest percentage of drug release. These results indicate the penetration ability of the drug through membranes.

\section{Microbiological assay}

The results in Table 3 showed that the percentage inhibition for standard solution was increased on increasing the drug concentration. The inhibition was found to be linear in the concentration range of 5 to $20 \mu \mathrm{g} / \mathrm{ml}$. The percentage inhibition of formulations F1 to F6 at $5 \mu \mathrm{g} /$ $\mathrm{ml}$ drug concentrations was found to be in range (52.63 to 63.15$) \%$ and at $10 \mu \mathrm{g} / \mathrm{ml}$ concentration the percentage inhibition was found to be in range (57.89 to 94.7$) \%$. Among them the formulation F2 showed highest percentage with $94.7 \%$ zone of inhibition after 24 hours at 10 $\mu \mathrm{g} / \mathrm{ml}$ concentration when compared with other formulations and control. Graphs from all formulations (as shown in figure 6) showed linearity with straight lines on plot between log concentration and \% inhibition and showed that on increasing drug concentration the percentage of inhibition also increased. The results also showed that there was a steady release of the drug and is capable of inhibiting microorganism staphylococcus aureus for $24 \mathrm{hrs}$. This indicated that the prepared vancomycin liposomes are efficient and also can inhibit the growth of microorganism staphylococcus aureus due to high drug diffusion.

\section{CONCLUSION}

Vancomycin hydrochloride has good water solubility but fails to absorb due to poor permeability. In the 
present work attempts were made to entrap the drug in liposome formulation using lecithin and cholesterol. Further the liposomes were prepared with incorporation of permeability enhancers propylene glycol, PEG400, PEG-600, Tween-80 and Span-60. The prepared liposomes are uniform discrete with spherical vesicular structure. They showed good entrapment efficiency and in vitro drug diffusion. Among different formulations of vancomycin liposomes F2 formulation (containing propylene glycol) has shown maximum entrapment efficieny and in vitro drug release when compared to other formulations and pure drug. The microbiological study also suggested that the formulation F2 is best among the six formulations. The results clearly indicated the usefulness of liposome formulation containing propyl-

\section{REFERENCES}

1. Cheung RP, DiPiro JT. Vancomycin: an update. Pharmacotherapy 1986; 6(4): 153-69.

2. The Extra Pharmacopoeia XXXI. Royal Pharmaceutical Society, London; 1996. 295-7.

3. Han DP, Wisniewski SR, Wilson LA, Barza M, Vine AK, Doft BH, et al. Spectrum and susceptibilities of microbiologic isolates in the endophthalmitis vitrectomy study. Am. J. Ophthalmol. 1996; 122(1): 1-17.

4. Satola SW, Lessa FC, Ray SM. Clinical and laboratory characteristics of invasive infections due to MRSA isolates demonstrating vancomycin MICs of $2 \mu \mathrm{g} / \mathrm{mL}$ : lack of effect of hVISA phenotype. J Clin Microbiol. Epub 2011/02/18. doi: 10.1128/JCM.01719-10

5. Maclayton DO, Suda KJ, Coval KA, York CB, Garey KW. Case-control study of the relationship between MRSA bacteremia with a vancomycin MIC of $2 \mathrm{microg} / \mathrm{mL}$ and risk factors, costs, and outcomes in patients undergoing hemodialysis. Clin Ther. 2006; 28 (8): 1208-16. doi: 10.1016/j. clinthera.2006.08.003

6. Sakoulas G, Moise-Broder PA, Schentag J, Forrest A, Moellering RC, Eliopoulos GM. Relationship of MIC and bactericidal activity to efficacy of vancomycin for treatment of methicillin-resistant Staphylococcus aureus bacteremia. J Clin Microbiol. 2004; 42(6): 2398- 402. doi: 10.1128/ JCM.42.6.2398-2402.2004

7. Holmes NE, Turnidge JD, Munckhof WJ, Robinson JO, Korman $\mathrm{TM}$, OSullivan MV, et al. Antibiotic choice may not explain poorer outcomes in patients with Staphylococcus aureus bacteremia and high vancomycin minimum inhibitory concentrations. J Infect Dis. 2011; 204(3): 340-7. doi: 10.1093/infdis/jir270

8. Moore CL, Osaki-Kiyan P, Haque NZ, Perri MB, Donabedian S, Zervos MJ. Daptomycin versus vancomycin for bloodstream infections due to methicillinresistant Staphylococcus aureus with a high vancomycin minimum inhibitory concentration: a case-control study. Clin Infect Dis. 2012; 54(1): 51-8. doi: 10.1093/cid/cir764.

9. Michelle L, Campbell BA, Dror Marchaim MD, Jason MPP, Bharath Sunkara $M D$, Suchitha Bheemreddy MD, et al. Treatment of Methicillin-Resistant Staphylococcus aureus Infections With a Minimal Inhibitory Concentration of $2 \mu \mathrm{g} / \mathrm{mL}$ to vancomycin. The Annals of Pharmacotherapy 2012; 46(12): 1587-97. ene glycol as permeability enhancer for the improvement of vancomycin release through membranes.

\section{CONFLICT OF INTEREST}

There is no conflict of interest.

\section{ACKNOWLEDGEMENT}

The authors are thankful to UGC (New Delhi, India) for providing financial assistance and encouraging research activities to GITAM Institute of Pharmacy, GITAM University, Visakhapatnam; Andhra Pradesh, India. The Authors are also thankful to $\mathrm{M} / \mathrm{s}$. Ther Dose Pharma Private Limited, Hyderabad for providing vancomycin hydrochloride.

10. Lucas RA, Bowtle WJ, Ryden R. Disposition of vancomycin in healthy volunteers from oral solution and semi-solid matrix capsules. J. Clin. Pharm. Ther. 1987; 12(1): 27-31.

11. Kajita M, Morishita M, Takayama K, Chiba Y, Tokiwa S, Nagai T. Enhanced enteral bioavailability of vancomycin using water-in-oil-in-water multiple emulsion incorporating highly purified unsaturated fatty acid. J. Pharm. Sci. 2000; 89(10): 1243-52.

12. Anderson KE, Eliot LA, Stevenson BR, Rogers JA. Formulation and evaluation of a folic acid receptortargeted oral vancomycin liposomal dosage form. Pharm. Res 2001; 18(3): 316-22.

13. Geary RS, Schlameus HW. Vancomycin and insulin used as models for oral delivery of peptides. J. Control. Rel. 1993; 23(1): 65-74.

14. Roop KK, Vyas SP, Farhan JA, Gaurav KJ. The theory and practice of Industrial Pharmacy. $4^{\text {th }}$ edition CBS Publishers \& distributers; 2013. 883.

15. Drulis-Kawa Z, Dorotkiewicz-Jach A. Liposomes as delivery systems for antibiotics. Int J Pharm. 2010; 387(1): 187-98.

16. Anada T, Takeda $\mathrm{Y}$, Honda $\mathrm{Y}$, Sakurai $\mathrm{K}$, Suzuki O. Synthesis of calcium phosphate-binding liposome for drug delivery. Bioorg Med Chem Lett. 2009; 19(15): 4148-50.

17. Han HD, Lee A, Hwang T, Song CK, Seong H, Hyun J, et al. Enhanced circulation time and antitumor activity of doxorubicin by comblike polymer incorporated liposomes. Journal Control Release 2007; 120(3): 161-8.

18. Chang CC, Liu DZ, Lin SY, Liang HJ, Hou WC, Huang WJ, et al. Liposome encapsulation reduces cantharidin toxicity. Food Chem Toxicol. 2008; 46(9): 3116-21.

19. Meng $M$, Liu $Y$, Wang $Y B$, Wang JC, Zhang $H$, Wang $X Q$, et al. Increase of the pharmacological and pharmacokinetic efficacy of negatively charged polypeptide recombinant hirudin in rats via parenteral route by association with cationic liposomes. Journal Control Release 2008; 128(2): 113-19.

20. Schellekens H, Klinger E, Muhlebach S, Brin JF, Storm G, Crommelin DJ, et al. The therapeutic equivalence of complex drugs. Regul Toxicol Pharmacol. 2011; 59(1): 176-83.

21. Steel JC, Cavanagh HM, Burton MA, Abu-Asab MS, Tsokos M, Morris JC, et al. Increased tumor localization and reduced immune response to adenoviral vector formulated with the liposome DDAB/DOPE. Eur J Pharm Sci. 2007; 30(5): 398-405. 